\title{
Growth Moderation in Slow-growing Mutants of Escherichia coli
}

\author{
By C. N. NEWMAN AND R. C. BOCKRATH \\ Department of Microbiology, Indiana University School of Medicine, \\ Indianapolis, Indiana 46202, U.S.A.
}

(Received 26 February 1974; revised 30 July 1974)

\begin{abstract}
SUMMARY
Mutants of Escherichia coli were induced by u.v. light and selected by the criterion that they formed small colonies on a nutrient agar at normal temperature. Nine slow-growing mutant strains were isolated. These mutants were characterized and compared during exponential growth in a nutrient medium with respect to doubling time, average cell mass, and DNA and RNA contents. The mutants showed only two groupings of doubling times, approximately $60 \mathrm{~min}$ and $35 \mathrm{~min}$, as compared with 20 min for the parent. The mutants were heterogeneous with regard to average cell mass, ranging from considerably larger than the parent to smaller. There was no constancy between average cell mass and the population doubling time. RNA:mass and DNA:mass ratios were similar among mutant strains with the same doubling time despite large variations in average cell mass.
\end{abstract}

\section{INTRODUCTION}

Knowledge concerning the underlying molecular physiology of bacterial growth and division has been sought from various perspectives. Auxotrophs and condition-dependent mutants have been selected and exploited to elucidate biochemical functions required for growth (Adelberg, 1966). However, implicit in the use of metabolite- or condition-dependent mutants was the requirement that the specific step altered by mutation be essential for growth. Consequently, this experimental approach has had a built-in bias guaranteeing the study of essential or critical functions.

The studies by Schaechter, Maaløe \& Kjeldgaard (1958) and others were therefore significant in that they represented an important digression from the 'grow, no grow' analysis of bacterial capabilities. They dealt largely with normal strains of Salmonella typhimurium or Escherichia coli and focused on the molecular compositions within bacteria growing in different media. Both steady-states and transitions were examined. In these investigations empirical values for cell mass, DNA, RNA and ribosome content were determined and related to specific growth rates. A given rate of exponential growth was generally accompanied by a given average cell mass and composition (for a summary and discussion of data see Maaløe \& Kjeldgaard, 1966).

The present study was conducted to explore variations in cellular composition prompted by genetic alterations rather than by environmental alterations. Since some genes are known which specify controlling elements such as repressors, and since metabolic pathways frequently interact and are sometimes mediated in part by alternative enzymic activities, it seems reasonable that certain genes may be particularly significant in the overall co-ordination of cellular growth. Such genes may be characterized as influential rather than essential. Cellular growth would be modified by the functions of these genes but would not be contingent upon them. Thus cells growing in a constant environment might show patterns of 
variation in molecular physiology according to specific differences in such influential genes. A direct inquiry regarding the possible existence and effects of influential genes could be initiated by selecting mutant strains exhibiting abnormal growth.

Several mutant strains of $E$. coli have been selected that grow more slowly than the parent strain. They were initially detected as smaller colonies on an enriched nutrient medium and then were cultured for study in a specific medium. These mutants were found to have aberrations in the usual patterns of cell mass and composition.

\section{METHODS}

Strains. The parent strain, Escherichia coli wwu, is a multi-auxotrophic derivative of E. coli $\mathrm{I}_{5} \mathrm{~T}^{-}$. Required metabolites are thymine, uracil, tryptophan, methionine, proline and arginine (Bockrath, Osborn \& Person, 1968). All slow-growing mutants were derived from wwu as described below.

Media and culture methods. Slow growth (SG) medium consisted of $8 \mathrm{~g}$ Difco tryptone and $4 \mathrm{~g}$ Difco yeast extract/1 of glass-distilled water. Nutrient broth consisted of $8 \mathrm{~g}$ Difco nutrient broth/1 water. A-I minimal-salts medium was supplemented with the required metabolites (Person \& Bockrath, 1964). The osmolarity of media was ascertained using an Osmette osmometer. When solid medium was desired Difco Bacto-agar was added to a final conch of $15 \mathrm{~g} /$.

Overnight cultures in SG medium were diluted $\mathrm{I}: \mathrm{IO}(\mathrm{v} / \mathrm{v})$ in the same medium and incubated at $37^{\circ} \mathrm{C}$ with shaking. After 2 to $3 \mathrm{~h}$ the cultures were diluted roo-fold in SG medium pre-warmed to $37^{\circ} \mathrm{C}$ and the bacteria were aerated by bubbling. The $E_{450}$ was determined at intervals using a Coleman Junior II spectrophotometer. Additionally, samples were removed from the growing culture, diluted in buffer (A-I minus glucose) and plated on to SG agar medium. Colonies were counted after incubation for $20 \mathrm{~h}$ at $37^{\circ} \mathrm{C}$. The doubling time of a culture was deduced from the slope of a straight line fitted by the method of least squares to several points representing the $\log$ of the colony-forming units (c.f.u.)/ml determined during exponential growth. When grown in A-I medium, bacteria were inoculated into a I $25 \mathrm{ml}$ flask containing Io $\mathrm{ml}$ of fully supplemented medium and were incubated overnight with shaking. The culture was then diluted 20 to Ioo times. Growth was monitored as described for SG medium.

The proportionality of extinction to cell mass. Mutant wi 74, when observed microscopically, showed a snake-like morphology, with individual bacteria being many times larger than the parent strain. In contrast, mutant WI 69 appeared much smaller than the parent strain. At extinctions between 0.05 and 0.20 in SG medium, several samples of each mutant and of the parent were collected on to tared filters $\left(0.45 \mu \mathrm{m}\right.$ pore-size), desiccated at $65^{\circ} \mathrm{C}$ and, at intervals, weighed on a Cahn electrobalance until constant weights were obtained. The net dry wt of bacterial samples were corrected for the net dry wt of medium adsorbing to filters. For each strain a slope of $\mathrm{I} \cdot 7$ extinction units $/ \mathrm{mg}$ bacteria/ml was obtained.

Mutagenesis. A culture of $E$. coli wwU was grown to approximately $2 \times 10^{8}$ bacteria $/ \mathrm{ml}$ in supplemented A-I medium. The cells were pelleted by centrifuging and resuspended in buffer to their original volume. Two $\mathrm{ml}$ of the suspension were irradiated with u.v. light sufficient to reduce the viable titre to $10^{2}$ to $10^{3}$ c.f.u. $/ \mathrm{ml}$ (approx. I000 ergs $/ \mathrm{mm}^{2}$ ).

Isolation of slow-growing mutants. After mutagenesis $0.1 \mathrm{ml}$ portions of the irradiated suspension of cells were inoculated into culture tubes, each containing $0.9 \mathrm{ml} \mathrm{SG}$ medium. The tubes were incubated on a shaker at $37^{\circ} \mathrm{C}$ for $2 \mathrm{~h}$. From each tube $0.1 \mathrm{ml}$ portions were taken, spread on SG agar medium and incubated at $37^{\circ} \mathrm{C}$ for $20 \mathrm{~h}$. Abnormally small 
colonies (potential mutants) were picked, suspended in $\mathrm{I}$ o $\mathrm{ml}$ of buffer and $\mathrm{O} \cdot \mathrm{I} \mathrm{ml}$ samples spread on to fresh SG agar plates. These plates were incubated at $37^{\circ} \mathrm{C}$ and periodically examined for colonies. Isolates producing colonies prior to $8 \mathrm{~h}$ were discarded. A random sampling of ten isolates which did yield visible colonies in $8 \mathrm{~h}$ was examined by liquid culture and none divided more slowly than the parent. Small colony isolates which failed to form visible colonies within $8 \mathrm{~h}$ were slow-growing mutants. These mutants were confirmed as $E$. coli by standard biochemical assays and were shown to have retained the six auxotrophic requirements of the parent strain. Back-mutation of certain mutants occurred occasionally, but was easily detected as heterogeneity in colony size on SG agar medium. All liquid cultures studied were routinely tested by streaking samples to single colonies. Individual mutant strains re-examined several times in the course of many months had unvarying rates of population growth.

Nucleic acid determinations. Cultures were grown in SG medium (I00 $\mathrm{ml}$ ) with aeration at $37^{\circ} \mathrm{C}$ to an extinction of 0.1 . The cells were harvested by centrifuging at $18000 \mathrm{~g}$ for Io min and each pellet was resuspended in a small volume of cold SG medium for recentrifuging. Two $\mathrm{ml}$ of cold $0.5 \mathrm{~N}$-perchloric acid (PCA) were added to the pellet which was then shaken vigorously. After $30 \mathrm{~min}$ at $4{ }^{\circ} \mathrm{C}$, the suspension was centrifuged as before and the pellet was washed with $3 \mathrm{ml}$ of cold PCA. After two additional centrifugings and washings with $2.5 \mathrm{ml}$ of absolute ethyl alcohol, $\mathrm{I} \cdot 0 \mathrm{ml}$ of $0.33 \mathrm{~N}-\mathrm{KOH}$ was added to the insoluble material. The centrifuge tube was covered tightly and incubated for $\mathrm{I} 8 \mathrm{~h}$ at $37^{\circ} \mathrm{C}$. This mixture was then cooled for $30 \mathrm{~min}$, cold PCA (I $\mathrm{ml}$ ) was added and the mixture was held for $30 \mathrm{~min}$ at $4{ }^{\circ} \mathrm{C}$. The solid material was pelleted at $12000 \mathrm{~g}$ for $\mathrm{I} 0 \mathrm{~min}$ in the cold and the supernatant was collected (fraction No. I). Another washing with $3.0 \mathrm{ml}$ of cold PCA was performed and the washing was added to fraction No. I. The solid material was resuspended in $3.0 \mathrm{ml} \mathrm{PCA}$ and heated in a boiling water bath for Io to $15 \mathrm{~min}$. Cooling at $4{ }^{\circ} \mathrm{C}$ for $45 \mathrm{~min}$ was followed by centrifuging in the cold as before. The supernatant was collected (fraction No. 2) and the precipitate was washed with $2.0 \mathrm{ml}$ of cold PCA. This washing was combined with fraction No. 2.

Fraction No. I contained hydrolysed RNA and fraction No. 2 contained hydrolysed DNA (Schmidt \& Thannhauser, 1945). Absorption at $260 \mathrm{~nm}$ against PCA was compared with standards of hydrolysed RNA (Nutritional Biochemicals Corp.) or DNA (MilesSeravac Co.) in PCA to determine absolute amounts. To determine nucleic acid per cell these values were divided by the number of c.f.u. in the original culture.

\section{RESULTS}

\section{Classification of mutants}

In isolating mutants separate cultures of irradiated $E$. coli wwU were incubated immediately after mutagenesis and before mutation expression and cell division. By selecting mutants from different culture vessels, the possibility that several isolates_were derived from the same mutated ancestor cell was eliminated.

Approximately $10^{5}$ colonies grown from irradiated suspensions were inspected to find the mutants discussed here. Approximately ${ }_{10}{ }^{2}$ small colonies were observed and tested; the majority were rejected because they grew as rapidly as the parent upon replating. The nine slow-growing mutants that were isolated could be divided into two groups on the basis of their respective doubling times in SG medium (Table I). Group I mutants had doubling times between 30 and $39 \mathrm{~min}$. Group II was composed of mutants $\mathrm{w}_{2} \mathrm{I}_{5}$ and $\mathrm{w}_{5}$ that had doubling times of $6 \mathrm{I}$ and $59 \mathrm{~min}$, respectively. 
Table I. Growth rate and composition of strains of E. coli grown in SG medium

\begin{tabular}{|c|c|c|c|c|c|c|c|c|c|}
\hline \multirow[t]{2}{*}{ Strain } & \multicolumn{2}{|c|}{ Division } & \multicolumn{2}{|c|}{ Mass/cell } & \multicolumn{2}{|c|}{ DNA } & \multicolumn{2}{|c|}{ RNA } & \multirow[b]{2}{*}{$\mathbf{G}: \mathbf{E}$} \\
\hline & A & B & C & D & $\mathrm{E}$ & $\mathbf{F}$ & $\mathrm{G}$ & $\mathrm{H}$ & \\
\hline \multicolumn{10}{|l|}{ Parent } \\
\hline WwU & 20 & $3 \cdot 0$ & $2 \cdot 11$ & $12 \cdot 4$ & 0.419 & 0.034 & $4 \cdot 86$ & 0.392 & I I 6 \\
\hline wwU* & 45 & $\mathrm{I} \cdot 3$ & $\mathrm{I} \cdot 20$ & $7^{\cdot} \cdot \mathrm{I}$ & 0.200 & 0.028 & $1 \cdot 38$ & 0.195 & $6 \cdot 9$ \\
\hline \multicolumn{10}{|l|}{ Group I } \\
\hline W I 74 & 39 & $I \cdot 5$ & $9 \cdot 22$ & $54 \cdot 3$ & $2 \cdot 44$ & 0.045 & $26 \cdot 9$ & 0.495 & II $\cdot 0$ \\
\hline W I90 & 33 & $1 \cdot 8$ & II $\cdot 6$ & $34 \cdot 3$ & $2 \cdot 10$ & 0.031 & $24 \cdot I$ & 0.353 & II 5 \\
\hline W 212 & 30 & $2 \cdot 0$ & 5.91 & $68 \cdot 8$ & $I \cdot 13$ & 0.032 & 10.9 & 0.313 & 9.6 \\
\hline W 188 & 35 & 1.7 & $3 \cdot 28$ & $19 \cdot 3$ & 0.624 & 0.032 & $6 \cdot 73$ & 0.349 & 10.9 \\
\hline W 26 & 34 & $\mathrm{I} \cdot 8$ & I.96 & I I 5 & 0.426 & 0.037 & 4.53 & 0.394 & $10 \cdot 6$ \\
\hline W 157 & 34 & $\mathrm{I} \cdot 8$ & $I \cdot 36$ & $8 \cdot 0$ & 0.233 & 0.029 & $2 \cdot 37$ & 0.296 & 10.2 \\
\hline WI69 & 33 & $1 \cdot 8$ & 0.92 & $5 \cdot 4$ & 0.184 & 0.034 & $I \cdot 6 I$ & 0.298 & $8 \cdot 8$ \\
\hline \multicolumn{10}{|l|}{ Group II } \\
\hline w 5 & 59 & $I \cdot O$ & $I \cdot 3 I$ & $7 \cdot 7$ & 0.170 & 0.022 & $1 \cdot 17$ & 0.152 & $6 \cdot 9$ \\
\hline w $5{ }^{\dagger}$ & 27 & $2 \cdot 2$ & $1 \cdot 32$ & $7 \cdot 8$ & 0.178 & 0.023 & $\mathrm{I} \cdot 57$ & 0.202 & $8 \cdot 5$ \\
\hline W 2 I 5 & $6 i$ & $I \cdot O$ & 0.97 & $5 \cdot 7$ & 0.147 & 0.026 & $I \cdot I 6$ & 0.204 & $7 \cdot 9$ \\
\hline
\end{tabular}

Columns record: A, doubling time (min); B, doublings $/ \mathrm{h} ; \mathrm{C}$, extinction $/ 1 \mathrm{r}^{9} \mathrm{c.f.u} . \mathrm{ml} ; \mathrm{D}$, mass $(\mu \mathrm{g}) / \mathrm{ro}^{7}$ c.f.u.; E, DNA $(\mu \mathrm{g}) / \mathrm{ro}^{7}$ c.f.u.; F, DNA:mass; G, RNA $(\mu \mathrm{g}) / \mathrm{IO}^{7}$ c.f.u.; and $\mathrm{H}$, RNA:mass.

* wwu was grown in a glucose-salts defined medium supplemented with the required metabolites.

$\dagger$ Mutant w5 was grown in SG medium made up to $390 \mathrm{~m}$-osmol/l with $\mathrm{NaCl}$.

\section{Relation of doubling time and nucleic acid composition}

The data in Table I show that the average amounts of DNA and RNA per cell varied considerably in the mutants; neither was directly correlated with the rate of division.

The smallest amount of DNA/cell was that for mutant w215, 0.0I $5 \mathrm{pg}$, and the largest amount was $0.244 \mathrm{pg} /$ cell of mutant WI74. The parent contained $0.042 \mathrm{pg} /$ cell. Assuming the $E$. coli genome has a mass weight of about 0.004 pg (Kubitschek \& Freedman, I97I), these values suggest that wwU had about to genome-equivalents/cell in this growth situation. Mutants W215 and WI74 would have had about four and 60 genome-equivalents, respectively.

The model of Cooper \& Helmstetter (1968) indicates that cultures having doubling times of 20 min should contain 5 to 6 genome-equivalents per cell. Experimentally, Forchhammer \& Lindahl (I97I) found that strain TAU-bar (which is another name for wWU) growing in nutrient broth contained $26 \mu \mathrm{g} \mathrm{DNA} / \mathrm{mg}$ dry wt. This number translates to approximately 6 genome-equivalents/cell. Thus the prediction by Cooper \& Helmstetter and the data of Forchhammer \& Lindahl contrast sharply with the nearly Io genome-equivalents/cell that we found in $E$. coli wwU growing in SG medium. To determine whether SG medium promoted abnormal accumulation of cellular DNA, the DNA content of wwU growing in nutrient broth was also determined. A value of $25 \mu \mathrm{g}$ of DNA/mg dry wt was found, an amount in agreement with the value of Forschhamer \& Lindahl (197r) for this strain. In another experiment the amount of DNA/cell in $E$. coli $\mathrm{B} / \mathrm{r}$ growing in SG medium was ascertained (a doubling time of $23 \mathrm{~min}$ ). The average of two determinations (each within $5 \%$ of the mean) was $0.026 \mathrm{pg} /$ cell, which converts to about 7 genomes. Thus growth in SG medium generally enriched cellular DNA content, an observation particularly striking in WwU. 


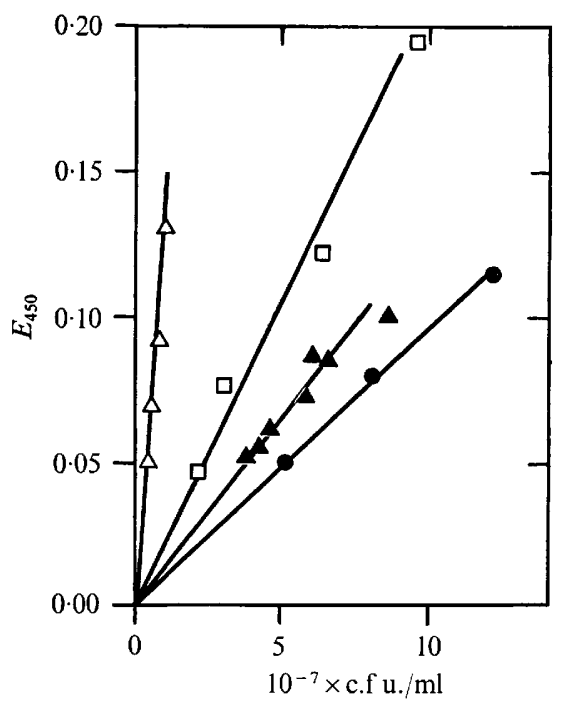

Fig. I. Differential plot of extinction and concentration of colony-forming units (c.f.u.) for strains growing in SG medium. $\triangle$, w I90; $\square$, wwU; $\Delta$, w5; $\bullet$, w 215.

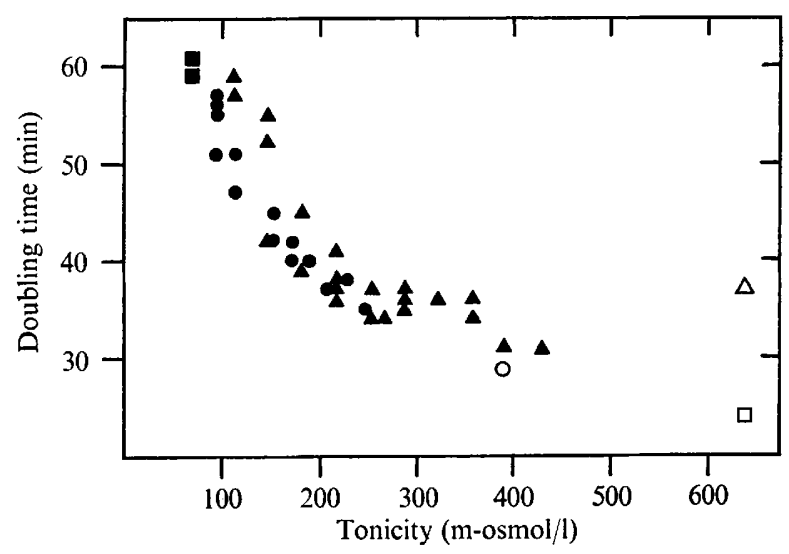

Fig. 2. Effects of tonicity on the growth rate of mutant w5. Mutant w5 was grown in SG medium (ש) and in $\mathrm{SG}$ medium supplemented with various solutes: $\mathrm{NaCl}(\Delta)$, sucrose $(\bullet), \mathrm{KCl}(\mathrm{O}), \mathrm{Na}_{2} \mathrm{SO}_{4}$ $(\triangle)$ or $\mathrm{MgCl}_{2}(\square)$.

\section{Relation of doubling time and average cell mass}

The concn of c.f.u. and the extinction, which is proportional to total mass (see Methods, and Koch, 1970), were determined during exponential growth of the mutants and of wwU in SG medium. A differential plot of these two parameters was then constructed for each strain. Straight lines were fitted to the data by the method of least squares and their slopes provided a measure of average cell mass (Maaløe \& Kjeldgaard, 1966). There was considerable variation in average cell mass among the mutants and wWU (Fig. I and Table I). No correlation was discerned between doubling time and average cell mass. Four of the group I mutants had a mass/cell greater than the parent, whereas the values for the other mutants were less than wwU. 


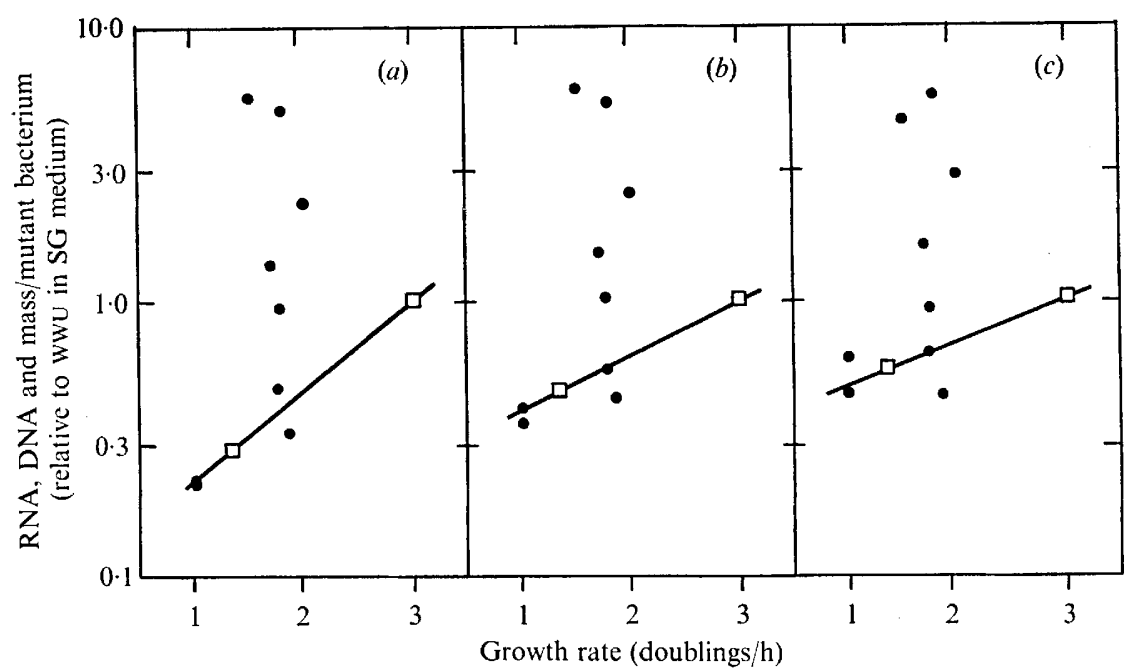

Fig. 3. Summary of DNA, RNA, mass and division rate data for the mutant strains and a comparison of this data with that for the parent strain. (a), RNA; $(b)$, DNA; $(c)$, mass. growing mutants in SG medium; $\square$, wwU in SG medium and defined medium (from Table I).

\section{Relation of average cell mass and nucleic acid composition}

The ratios of nucleic acid to mass were relatively constant regardless of the wide variation in nucleic acid content per cell. Values for DNA:mass and for RNA:mass for the various mutants of group I differed by less than $33 \%$ from the means of these values. The means were 0.034 and 0.357 , respectively. Group II mutants had mean values of 0.024 and 0.178 , respectively. The ratios of RNA:DNA indicated a mean value of 10.5 for group I mutants and a mean value of 7.4 for group II mutants; wwU had a value of I I.5. No mutant had an RNA:DNA value equal to, or greater than, that of wwU even though several mutants had per cell amounts of DNA, RNA or mass greater than wwU.

\section{Tonicity effects on mutant w5}

One slow-growing mutant was capable of a variety of division rates in response to differences in the tonicity of the SG medium. Escherichia coli $\mathrm{w}_{5}$ had a doubling time in SG medium of $59 \mathrm{~min}$, but this time could be shortened by a factor of about two in the presence of the appropriate concentration of $\mathrm{NaCl}, \mathrm{MgCl}_{2}, \mathrm{Na}_{2} \mathrm{SO}_{4}, \mathrm{KCl}$ or sucrose (Fig. 2). Neither the other mutants nor the parent showed a similar response to variation in tonicity.

RNA and DNA per cell of mutant w5 dividing with a doubling time of about 30 or $60 \mathrm{~min}$, were examined. The shorter doubling time was obtained by adding $\mathrm{NaCl}, 172 \mathrm{mM}$, to the $\mathrm{SG}$ medium. While no difference in DNA content was noted, cellular RNA levels did change. The more rapidly dividing cells contained greater amounts of RNA and had larger RNA: DNA ratios than the more slowly dividing cells (Table I). Mutant w5 was grown in SG media of different tonicity and the average cell mass was determined. There were no measurable differences in the average cell masses of this mutant dividing at the different rates.

\section{DISCUSSION}

The slow-growing mutants of $E$. coli fell into two groups on the basis of their doubling times. Group I mutants had doubling times of 30 to 40 min and group II mutants had doubling times of about $60 \mathrm{~min}$. Mutants with doubling times greatly in excess of $60 \mathrm{~min}$ could 
have existed, but incubation for a few extra days did not reveal any. Mutants with doubling times between $60 \mathrm{~min}$ and the range of 30 to $40 \mathrm{~min}$ should have been detectable but none were found. Moreover, an independent isolation of ten additional slow-growing mutants which were not studied in as much detail as those described here also showed only group I and group II doubling times. Therefore, it would seem that slow-growing mutants accommodate their respective defects by entraining to one of two specific alternative doubling times.

Figure 3 summarizes some of the data from Table $\mathrm{I}$ for the nine mutants, and compares these values to those for the parent strain wwU growing at two rates of division (a doubling time of 45 min was effected by growth in defined medium rather than SG medium). The lines in this Figure intercepting the values for wWU are drawn to estimate the variations in DNA, RNA and mass with division rate when growth is moderated by media alone. They are similar to those of Maaløe \& Kjeldgaard (I966). Only mutants W2 I 5, w5 and W I 57 yielded data which fall on or near these lines. Therefore it seems that most of the mutants of this study do not have defects which simply affect permeation systems or the utilization of metabolites. Presumably such defects would shield endogenous metabolism from components in the nutrient environment and cause the mutants to mimic cells growing in media containing less nutrients.

It has been shown that the amount of DNA per cell in E. coli is a function of the growth rate when this is moderated by the composition of the medium (Cooper \& Helmstetter, 1968; Helmstetter, 1969). Variation in growth rate, as moderated by genetic alterations in the mutants of this study, did not indicate such a correspondence with DNA/cell (Fig. $3 b$ ). Additionally, mutant w5 growing in media of varying tonicity did not show such a correspondence. The DNA content/cell remained approximately proportional to cell mass regardless of the division rate.

There is no clear explanation for the wide variation in average cell mass. Certainly a continuous association between doubling time and cell mass, as previously demonstrated in single strains of enteric bacteria growing in different media, was not manifest in the slowgrowing mutants (Fig. $3 c$ ). Zaritsky \& Pritchard (1973) have demonstrated unbalanced growth in thymine-requiring strains of $E$. coli growing in very low thymine concentrations (less than $\mathrm{I} \mu \mathrm{g} / \mathrm{ml}$ ). However, by isotopic dilution we have estimated the concentration of thymine in SG medium to be $2 \mu \mathrm{g} / \mathrm{ml}$. This level of thymine, and the probable existence of deoxyribosides in SG medium, should have been sufficient to permit balanced growth to the cell densities of this study. Moreover, microscopic examination of several slow-growing mutants showed them to be considerably larger than wwU in length, whereas the effect of low thymine observed by Zaritsky \& Pritchard (I973) was increased cell width. It seems possible that the genetic defects evident in slow-growing mutants principally affect the coordination between cell division and cell mass, and that these defects also affect the autocatalytic capabilities of the mutants to increase the steady-state doubling times.

These results suggest that abnormal growth, as opposed to normal growth or no growth, perhaps could be explored effectively in bacteria by the continued study of slow-growing mutants.

The authors acknowledge with sincere appreciation the help of C. C. McDonald and K. Spear, who isolated the first mutant, w5, and J. Smith, who isolated the additional mutants indicated in the Discussion. The general support of Dr E. W. Shrigley and advice of Dr Ann Matthysse are also acknowledged with thanks. 


\section{REFERENCES}

Adelberg, E. A. (1966). Papers on Bacterial Genetics. Boston: Little, Brown.

Bockrath, R. C., Osborn, M. \& Person, S. (1968). Nonsense suppression in a multiauxotrophic derivative of Escherichia coli $\mathrm{I}_{5 \mathrm{~T}^{-}}$: identification and consequences of an amber triplet in the deoxyribomutase gene. Journal of Bacteriology 96, I46-164.

COOPER, S. \& HelmSTETTER, C. E. (I968). Chromosome replication and the division cycle of Escherichia coli B/r. Journal of Molecular Biology 31, 519-540.

ForchHammer, J. \& Lindaht, L. (197I). Growth rate of polypeptide chains as a function of cell growth rate in a mutant of Escherichia coli 15. Journal of Molecular Biology 55, 563-568.

HeLmstetTer, C. E. (1969). Sequence of bacterial reproduction. Annual Review of Microbiology 23, 223-234.

Koch, A. L. (1970). Turbidity measurements of bacterial cultures in available commercial instruments. Analytical Biochemistry 38, 252-259.

KúBITSCHEK, H. E. \& FrEEDMAN, M. L. (I97I). Chromosome replication and the division cycle of Escherichia coli $\mathrm{B} / \mathrm{r}$. Journal of Bacteriology 107, 95-99.

MaAløe, O. \& KJeldgaARd, N. O. (I966). Control of Macromolecular Synthesis. New York: W. A. Benjamin.

Person, S. \& Bockrath, R. C. (1964). Differential mutation produced by the decay of incorporated tritium compounds in E. coli. Biophysical Journal, 4, 355-365.

SChaEchter, M., MAaløe, O. \& KJeldgaARD, N. O. (1958). Dependency on medium and temperature of cell size and chemical composition during balanced growth of Salmonella typhimurium. Journal of General Microbiology 19, 592-606.

SCHMIDT, G. \& ThanNHAUSER, S. J. (I945). A method for the determination of desoxyribonucleic acid, ribonucleic acid and phosphoproteins in animal tissue. Journal of Biological Chemistry I6r, 83-89.

Zaritsky. A. \& Pritchard, R. H. (1973). Changes in cell size and shape associated with changes in the replication time of the chromosome of Escherichia coli. Journal of Bacteriology II4, 824-837. 